\section{Discussion}

The first description of the epigastric pain reproduction test showed that this pain could be reproduced by weak acid in the lower oesophagus but not in every patient with a duodenal ulcer (Earlam, 1970). This study was undertaken to analyse the quantitative aspects of the test and to investigate further those in whom it was negative. It has now been shown that all patients with duodenal ulceration awoken by epigastric pain in the four weeks before the test had a positive reaction (mean $37 \mathrm{ml}$ ) and that the test must not be considered negative until at least $125 \mathrm{ml} 0 \cdot 1 \mathrm{~N} \mathrm{HCl}$ has been perfused into the lower oesophagus. The classification of epigastric pain according to when it last occurred at night is admittedly a crude method of assessing when severe pain last occurred, but it is taken as the best objective measurement of this autonomic pain available at the moment. It is not necessary for a patient to be awoken at night before having a positive pain reproduction test, so the use of night pain as the sole indication of the severity of duodenal ulcer pain is obviously limited.

The reliability of the test, when epigastric pain had been present recently, together with the further experiments to neutralize acid in the stomach and show that the gastric mucosa is insensitive to acid are considered further evidence to suggest that the epigastric pain of duodenal ulceration arises from the lower oesophagus. When night pain is used as an indication of when the pain was last severe there is no really clear correlation between pain and the amount of acid needed to reproduce it. This discrepancy could be caused by inherently different sensitivities of the lower oesophagus to this stimulus. There is, however, some evidence to suggest that patients with a duodenal ulcer but without epigastric pain have a more competent gastrooesophageal junction than those with such pain and since it would be more capable of protecting the lower oesophageal mucosa from the effects of gastric reflux (Earlam, 1971).

For a long time it has been known that the severity of duodenal ulcer symptoms does not necessarily depend on the radiological appearances of the duodenum. If the epigastric pain of duodenal ulceration arises from the lower oesophagus and not the ulcer itself some of the incongruities of these symptoms would disappear and patients could be assessed more accurately for medical or surgical treatment.

I would like to thank the physicians and surgeons in charge of these patients at The London Hospital and Mile End Hospital for permission to perform these studies and the patients themselves for their co-operation.

\section{References}

Bernstein, L. M., and Baker, L. A. (1958). Gastroenterology, 34, 760.

Earlam, R. J. (1970). British Medical fournal, 4, 714

Earlam, R. J. (1971). British fournal of Surgery, 58, 296.

Fyke, F. E., jun., Code, C. F., and Schlegel, J. F. (1956). Gastroenterologia (Basel), 86, 135.

\title{
Prospective Study of Serum Cholesterol Levels during First Year of Life*
}

\author{
JUDITH M. DARMADY， AUDREY S. FOSBROOKE， JUNE K. LLOYD
}

British Medical fournal, 1972, 2, 685-688

\section{Summary}

A longitudinal prospective study of serum cholesterol concentrations during the first year of life has been carried out in 302 healthy babies. The results show that serum cholesterol estimations in cord blood cannot be used as a screening test for the diagnosis of familial hypercholesterolaemia. The only child subsequently found to have the condition had a cord serum cholesterol of 85 $\mathrm{mg} / 100 \mathrm{ml}$ compared with the mean value for the group of $78 \mathrm{mg} / 100 \mathrm{ml}$. The babies who had cord values greater than $100 \mathrm{mg} / 100 \mathrm{ml}$ had values distributed throughout the normal range when re-examined at 1 year of age. Serum cholesterol concentrations during the early months of life were markedly influenced by the type of milk fed; it is suggested that investigations to establish the diagnosis of familial hypercholesterolaemia are deferred until the child is about 1 year old and feeding with cows' milk and mixed diet is established.

Values obtained for serum cholesterol concentrations ( $\mathrm{mg} / 100 \mathrm{ml}$, mean \pm 1 S.D.) in healthy infants in this

* Part of this work was presented at the 19th Colloquium on Protides of
the Biological Fluids (1971) and at the XIII International Congress of the Biological Fluid
Pediatrics (1971).

Department of Child Health, Institute of Child Health, London W.C.1 JUDITH M. DARMADY, M.R.C.P., Research Fellow (At present, Lecturer, Department of Child Health, University of Southampton) AUDREY S. FOSBROOKE, M.SC., Senior Lecturer JUNE K. LLOYD, M.D., F.R.C.P., Reader study were: at birth $78 \pm 23$, at 1 week $155 \pm 31$, at 6 weeks $155 \pm 31$, at 4 months $184 \pm 36$, at 8 months $195 \pm 37$, and at 1 year $191 \pm 36$.

\section{Introduction}

Familial hypercholesterolaemia (familial type II hyperlipoproteinaemia in the classification of Fredrickson et al. (1967)) is a dominantly inherited condition characterized by an increased concentration of serum betalipoprotein and cholesterol; triglyceride levels are usually normal. It is associated with an increased risk of ischaemic heart disease in early adult life (Slack, 1969). It is not yet known whether treatment that lowers serum cholesterol will prevent or delay the onset of ischaemic heart disease, but if such measures are to have maximum effect treatment should probably be started as early as possible-that is, during the childhood years. It therefore becomes important to establish the earliest age at which the diagnosis can be made.

It has been suggested that the diagnosis may be made at birth, and a few isolated cases have been reported (Lewis et al., 1967; Wolff, 1967; Lees et al., 1969) of babies who had a high cord serum cholesterol concentration (greater than $100 \mathrm{mg} / 100 \mathrm{ml}$ ) and who were subsequently shown to have familial hypercholesterolaemia. More recently two systematic studies have been reported. Kwiterovitch et al. (1970) examined the cord blood of 15 infants in whom a parent was known to have familial hypercholesterolaemia. The serum cholesterol concentration and, in particular, the betalipoprotein cholesterol were considered to be increased in seven of these babies; 8 of the 15 children were followed-up and among these one false-positive and one false-negative diagnosis have been reported. Glueck 
et al. (1971) estimated the cord serum cholesterol concentrations in 1,800 consecutive live births; values greater than $100 \mathrm{mg} / 100$ $\mathrm{ml}$ were found in 65 babies, and investigation of both parents of 26 of these infants showed that nine mothers and two fathers had increased cholesterol and betalipropotein levels. Examination of the mother only of a further 23 babies showed three of these mothers to have raised cholesterol and betalipoprotein.

Although the parents with raised cholesterol were all considered to have familial type II hyperlipoproteinaemia it is possible that in some of the mothers the diagnosis could not be firmly established because at the time the blood was taken the serum cholesterol concentration was still raised as a result of the recent pregnancy. Oliver and Boyd (1955) found that even at 20 weeks postpartum serum cholesterol was higher than the level found in the first trimester of pregnancy.

In the present investigation a prospective study of serum lipids was carried out in infants throughout the first year of life. Its purpose was to establish the relation between cord serum cholesterol levels and the values subsequently achieved in individual babies, and to determine whether a diagnosis of familial hypercholesterolaemia could be made with certainty during the first year of life. In addition, normal values for serum cholesterol during this period have been obtained.

\section{Methods}

Cord blood was obtained from 302 full-term babies born at the Hammersmith Hospital. The study and its aims were explained to the mothers and their consent was obtained. Blood samples were taken by capillary puncture from a heel or finger at 1 week, 6 weeks, 4 months, 8 months, and 1 year of age. The number of babies investigated in each age group is given in Table I; for practical reasons only a proportion of the babies were examined at 8 months. No attempt was made to take blood in the fasting state or to standardize the time in relation to the previous feed; the interval from the last feed was, however, recorded for each baby at all visits, as were the weight and diet. For analysis of the data in relation to the type of milk fed the babies were grouped into those who were breast-fed, those receiving a full-cream or half-cream cows' milk, and those having a modified cows' milk with increased amounts of polyunsaturated fatty acids (S-M-A; Scientific Milk Adaptation*). No attempt was made to influence the feeding regimen.

Those babies whose serum cholesterol was $240 \mathrm{mg} / 100 \mathrm{ml}$ or over at 1 year of age had a further sample taken, on this occasion in the fasting state, and a study was made on fasting blood obtained from their first-degree relatives. The limit of $240 \mathrm{mg} / 100 \mathrm{ml}$ was chosen arbitrarily in the expectation that the serum cholesterol of any infant with familial hypercholesterolaemia would be above this level at 1 year of age.

Lipids were extracted from serum with ethanol/diethyl ether $(3: 1)$. For analyses on cord blood $0.25 \mathrm{ml}$ of serum was used and for capillary samples $0.1 \mathrm{ml}$ was usually extracted. Total cholesterol was estimated by a semi-automated method (Fosbrooke and Pringle, 1970), and triglyceride by quantitative gas liquid chromatography (Fosbrooke and Tamir, 1968). Paper electrophoresis of serum lipoproteins was performed by the method of Salt and Wolff (1957).

\section{Results}

\section{SERUM CHOLESTEROL DURING FIRST YEAR}

Serum cholesterol concentrations in cord blood and at intervals during the first year of life are shown in Table I. In addition to the wide range in each age group, the values in individual babies were found to fluctuate considerably. At each age examined the girls had somewhat higher mean concentrations than the boys;

* John Wyeth and Brother Limited; linoleic acid constitutes about $20 \%$ of total fatty acids.
TABLE I-Serum Cholesterol Concentration during First Year of Life

\begin{tabular}{|c|c|c|c|c|c|c|c|}
\hline \multirow{3}{*}{ Age } & & \multicolumn{6}{|c|}{ Serum Cholesterol $(\mathrm{mg} / 100 \mathrm{ml}$, mean \pm 1 S.D. $)$} \\
\hline & & \multicolumn{2}{|c|}{ Total } & \multicolumn{2}{|c|}{ Boys } & \multicolumn{2}{|c|}{ Girls } \\
\hline & & No. & & No. & & No. & \\
\hline $\begin{array}{l}\text { Birth } . . \\
1 \text { week } \\
6 \text { weeks } \\
4 \text { months } \\
8 \text { months } \\
1 \text { year }\end{array}$ & 8 & $\begin{array}{r}302 \\
300 \\
257 \\
265 \\
60 \\
273\end{array}$ & $\begin{array}{r}78 \pm 23 \\
155 \pm 31 \\
155 \pm 31 \\
184 \pm 36 \\
195 \pm 37 \\
191 \pm 36\end{array}$ & $\begin{array}{r}155 \\
156 \\
134 \\
140 \\
31 \\
143\end{array}$ & $\begin{array}{r}76 \pm 22 * \\
149 \pm 31 \dagger \\
152 \pm 29 \\
182 \pm 32 \\
188 \pm 36 \\
189 \pm 35\end{array}$ & $\begin{array}{r}147 \\
144 \\
123 \\
125 \\
29 \\
130\end{array}$ & $\begin{array}{c}81 \pm 25^{*} \\
162 \pm 29+ \\
159 \pm 32 \\
186 \pm 41 \\
203 \pm 38 \\
192 \pm 38\end{array}$ \\
\hline
\end{tabular}

$* \mathrm{P}$
$+\stackrel{\mathrm{P}}{<}<0.05$
0.001

TABLE II-Relation between Milk Fed and Serum Cholesterol Concentration

\begin{tabular}{|c|c|c|c|c|c|c|}
\hline \multirow{3}{*}{ Type of Milk } & \multicolumn{6}{|c|}{ Serum Cholesterol Concentration $(\mathrm{mg} / 100 \mathrm{ml}$, mean \pm S.D.) } \\
\hline & \multicolumn{2}{|c|}{1 Week } & \multicolumn{2}{|c|}{6 Weeks } & \multicolumn{2}{|c|}{4 Months } \\
\hline & No. & & No. & & No. & \\
\hline $\begin{array}{l}\text { Human } \\
\text { Cows' }\left\{\begin{array}{l}\text { full cream } \\
\frac{1}{2} \\
\text { cream }\end{array}\right. \\
\text { S-M-A } \\
. .\end{array}$ & $\begin{array}{r}127 \\
80 \\
67\end{array}$ & $\begin{array}{l}156 \pm 30 \\
150 \pm 27 \\
156 \pm 27 \\
\end{array}$ & $\begin{array}{r}24 \\
148 \\
19\end{array}$ & $\begin{array}{l}175 \pm 29 \\
158 \pm 26 \\
129 \pm 27\end{array}$ & $\begin{array}{r}15 \\
199 \\
31\end{array}$ & $\begin{array}{l}196 \pm 30 \\
190 \pm 33 \\
149 \pm 30\end{array}$ \\
\hline $\begin{array}{l}\text { Human } v . \text { cows' } \\
\text { Cows'v. S-M-A }\end{array}$ & \multicolumn{2}{|c|}{ N.S. } & \multicolumn{2}{|c|}{$\begin{array}{l}P<0.004 \\
P<0.001\end{array}$} & \multicolumn{2}{|c|}{$\begin{array}{l}\text { N.S. } \\
\text { P }<0.001\end{array}$} \\
\hline
\end{tabular}

Number of babies at each age is less than the total number examined; the remainder had been fed on more than one type of milk.

the difference was statistically significant at birth $(P<0.05)$ and at 1 week of age $(P<0.001)$.

The relation between the type of milk fed and the serum cholesterol concentration is shown in Table II. At 1 week of age breast-fed babies had similar values to the infants fedon a half-cream or full-cream cows' milk preparation, but by 6 weeks the breast-fed infants had significantly higher mean levels than those fed on a cows' milk preparation; babies fed on S-M-A had the lowest values. At 4 months the babies fed on S-M-A again had significantly lower levels than those fed on cows' milk. Variation in the interval between blood collection and the last feed over a range of 0 to 8 hours did not have any demonstrable effect on the serum cholesterol concentration.

Comparison of the cholesterol concentration at birth and at 1 year in individual babies showed a weak positive correlation $(\mathrm{r}=0.28, \mathrm{P}<0.001)$. Of the 34 babies who had cord values of $100 \mathrm{mg} / 100 \mathrm{ml}$ or over, 30 were re-examined at 1 year and Fig. 1 shows that their serum cholesterol levels at this age were widely distributed throughout the values for the whole group.

\section{FAMILY STUDIES}

Of 274 babies examined at 1 year 24 had serum cholesterol concentrations of $240 \mathrm{mg} / 100 \mathrm{ml}$ or greater, and repeat observations with studies of the first-degree relatives were made in 23 (Fig. 2). These observations were carried out on average seven weeks after the "one year" blood sample had been taken.

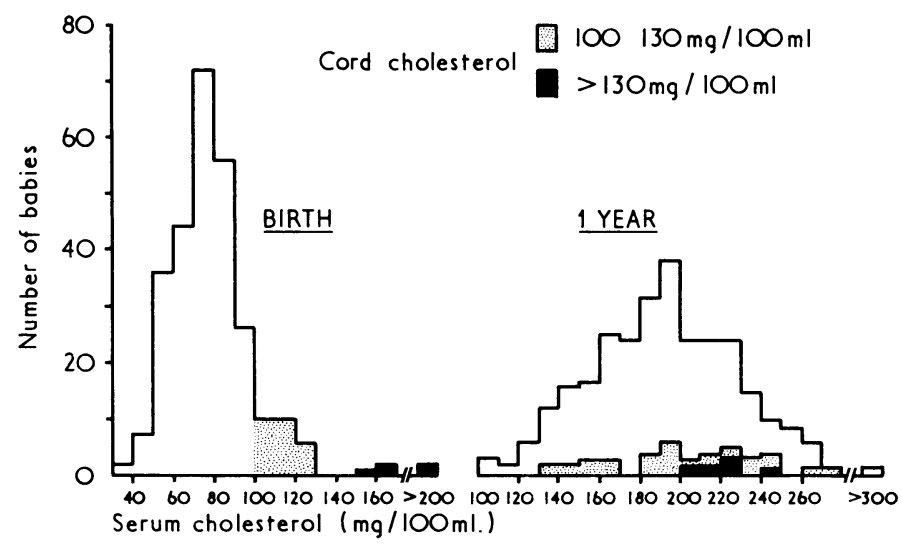

FIG. 1 -Serum cholesterol concentration in 271 babies at birth and at 1 year. 


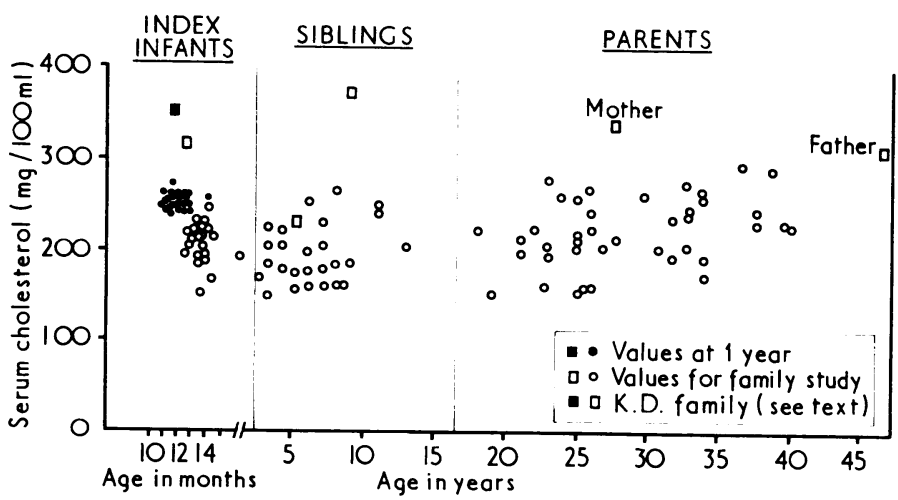

FIG. 2-Serum cholesterol concentration in first-degree relatives of infants having serum cholesterol above $240 \mathrm{mg} / 100 \mathrm{ml}$ at age of 1 year.

In all infants the serum cholesterol in the repeat sample was lower than it had been at 1 year. The family studies showed that one infant (K.D.) had familial hypercholesterolaemia as had her mother and one of her two siblings; all these individuals had raised serum cholesterol, normal serum triglyceride, and the typical lipoprotein pattern on electrophoresis. The father, whose cholesterol concentration was $315 \mathrm{mg} / 100 \mathrm{ml}$, had serum triglyceride of $220 \mathrm{mg} / 100 \mathrm{ml}$ and a marked prebetalipoprotein band on electrophoresis (type IV pattern).

\section{Discussion}

The present investigation shows that estimation of cord serum cholesterol concentration cannot be used as a screening test for familial hypercholesterolaemia. In the only patient in the study in whom the diagnosis was established this would have been missed if the "cut-off" value of $100 \mathrm{mg} / 100 \mathrm{ml}$ for cord serum cholesterol suggested by Glueck et al. (1971) had been adopted; in this patient the cord value of $85 \mathrm{mg} / 100 \mathrm{ml}$ was only slightly greater than the mean for the group as a whole $(78 \mathrm{mg} / 100 \mathrm{ml})$. Of 30 children with cord serum cholesterol greater than $100 \mathrm{mg} /$ $100 \mathrm{ml}$ only five had concentrations above $240 \mathrm{mg} / 100 \mathrm{ml}$ at 1 year of age, and on re-examination values had fallen below this level in four; family studies in all five children were negative. Although the level of $240 \mathrm{mg} / 100 \mathrm{ml}$ at 1 year of age had been chosen arbitrarily at the beginning of the study as an upper limit of "normality" subsequent analysis of our data has shown that this value falls well within 2 standard deviations above the mean for the whole group at this age.

The difficulty of making a diagnosis of familial hypercholesterolaemia in individual patients on the basis of serum cholesterol levels alone is well recognized (Fredrickson, 1971) but we do not consider that the diagnosis could be made with levels below $240 \mathrm{mg} / 100 \mathrm{ml}$. We also think it unlikely that any child with familial hypercholesterolaemia would have levels below 240 $\mathrm{mg} / 100 \mathrm{ml}$ at 1 year that would rise substantially later in childhood. In our experience of children with familial hypercholesterolaemia serum cholesterol concentrations have remained remarkably constant throughout childhood unless treatment has been instituted. Likewise in normal children longitudinal studies have shown levels to be fairly constant up to puberty (Lee, 1967; Mulligan et al., 1969).

During the first year of life the clinical significance of serum cholesterol concentrations in individual infants is difficult to interpret. Fig. 3 gives the values of serum cholesterol during this period in two infants and shows that a raised level in the early months cannot be taken as evidence of familial hypercholesterolaemia. Both children had values greater than 2 standard deviations above the mean for the group at 6 weeks, 4 months, and 8 months; at 1 year the level in one child (S.G.) had fallen to within the normal range and family studies showed no lipoprotein abnormalities, while in the other child (K.D.) levels remained high and the diagnosis of familial hypercholesterolaemia was established by family studies. One reason for

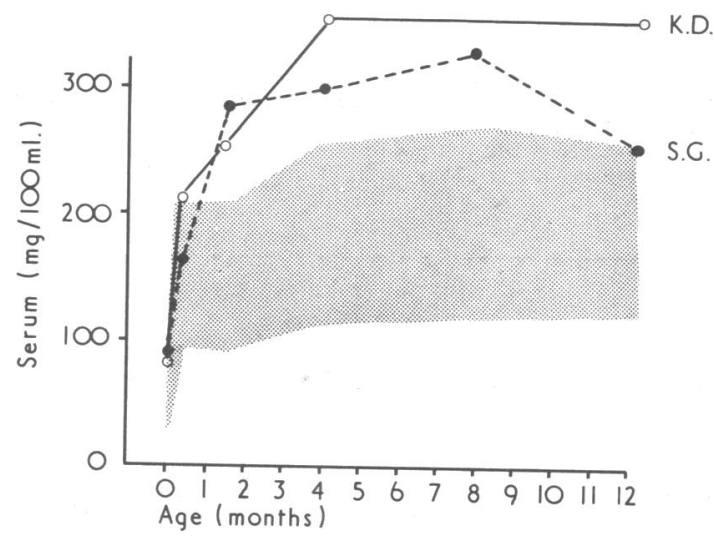

FIG. 3-Serum cholesterol concentration in two infants during the first year. (Reprinted, with permission, from Protides of the Biological Fluids, 19th Colloquium, edited by H. Peeters, Pergamon Press Ltd., Oxford, 1972.)

the high serum cholesterol concentration in S.G. during the early months of life may have been the type of milk fed. This infant was breast-fed up to 8 months, and our observations on the influence of the type of milk fed are in agreement with those of others (Goalwin and Pomerannge, 1962; Hansen et al., 1964) in showing that infants receiving breast milk tend to have the highest serum cholesterol levels, whereas those fed on milks containing vegetable oils with a high proportion of polyunsaturated fatty acids have the lowest revels. It has also been shown that once weaning has been established, and more dairy and meat products have been introduced into the diet, the low cholesterol levels of babies previously fed milks rich in polyunsaturated fatty acids will rise (Goalwin and Pomerannge, 1962). All the babies in our study were taking cows' milk and a mixed diet by the time the final blood sample was obtained.

The apparent reduction in serum cholesterol which we have observed between estimations at about 1 year (mean age 51 weeks) and those obtained some seven weeks later (mean age 58 weeks) is of surprising magnitude. The mean cholesterol concentration at an average age of 51 weeks in 22 infants was $257 \mathrm{mg} / 100 \mathrm{ml}$, whereas for the same infants at an average age of 58 weeks it was $214 \mathrm{mg} / 100 \mathrm{ml}$; in every child the second value was lower. We do not consider that the overnight fast before obtaining the second sample could account for the change. Some reduction is to be expected when a "top" segment of a population (in this case infants with serum cholesterol greater than $240 \mathrm{mg} / 100 \mathrm{ml}$ ) is subjected to repeat analysis because values will then trend towards the mean as a result of both biological and analytical variation.

We are grateful to the parents for their co-operation, and to the staff of the Departments of Obstetrics and of Child Health at the Hammersmith Hospital, and the many general practitioners and health visitors who gave help and encouragement and provided facilities for our study. The analyses were carried out by Mr. Barnard, Mrs. Mullen, and Mr. Pringle, and Miss Slade gave computer assistance.

This work was supported by a Ministry of Health grant for locally sponsored research and B.M.A. Research Awards in 1970 and 1971. Requests for reprints should be addressed to Dr. J. M. Darmady, Department of Child Health, Southampton Children's Hospital, Winchester Road, Southampton SO9 4WR.

\section{References}

Fredrickson, D. S. (1971). British Medical fournal, 2, 187

Fredrickson, D. S., Levy, R. I., and Lees, R. S. (1967). New England fournal of Medicine, 276, 148 .

Fosbrooke, A. S., and Pringle, G. A. (1970). Clinica Chimica Acta, 30, 47.

Fosbrooke, A. S., and Tamir, I. (1968). Clinica Chimica Acta, 28, 517.

Glueck, C. J., Heckman, F., Schoenfeld, M., Steiner, P., and Pearce, W (1971). Metabolism, 20, 597. 
Goalwin, A., and Pomerannge, J. (1962). Archives of Pediatrics, 79, 58. Hansen, A. B., Wiese, H. F., and Adam, D. J. D. (1964). American fournal of Clinical Nutrition, 15, 11 .

Kwiterovitch, P. O., Levy, R. I., and Fredrickson, D. S. (1970). Circulation, 41-42, Suppl. No. III, p. il.

Lee, V. A. (1967). American fournal of Clinical Nutrition, 20, 5

Lees, G. B., Culley, G. A., Lawson, M. J., Adcock, L. L., and Krivit, W. (1969). Circulation, 39, 183.
Lewis, L. A., Brown, H. B., and Green, J. G. (1967). Circulation, 35-36, Suppl. No. II, p. 24

Mulligan, J. E., Roach, M. R., and Talner, W. S. (1969). Journal of the American Dietetic Association, 49, 309.

Oliver, M. F., and Boyd, G. S. (1955). Clinical Science, 14, 15

Salt, H. B., and Wolff, O. H. (1957). Archives of Disease in Childhood, 32, 404.

Slack, J. (1969). Lancet, 2, 1380.

Wolf, O. H. (1967). Proceedings of the Royal Society of Medicine, 20, 1147.

\title{
Effect of Nitrazepam in Chronic Obstructive Bronchitis
}

\author{
J. GADDIE, J. S. LEGGE, K. N. V. PALMER, J. C. PETRIE, R. A. WOOD
}

British Medical fournal, 1972, 2, 688-689

\section{Summary}

The effect of nitrazepam on ventilatory capacity and arterial blood gas tensions was studied in a double-blind controlled crossover trial in six patients with chronic obstructive bronchitis in ventilatory failure (raised $\mathbf{P a C O}_{2}$ ). Nitrazepam produced a fall in ventilatory capacity and worsening of the ventilatory failure. In the sixth patient, while on the active drug, the $\mathrm{PaO}_{2}$ fell from 48 to $35 \mathrm{~mm} \mathrm{Hg}$ while the $\mathrm{Paco}_{2}$ tension rose from 59.5 to $68 \mathrm{~mm} \mathrm{Hg}$. It is suggested that nitrazepam is contraindicated in patients with severe chronic obstructive bronchitis.

\section{Introduction}

Nitrazepam is a hypnotic drug which is finding increased clinical usage because of its efficacy and safety. Sleep is induced by depressing the activity of the amygdala and hippocampus (Schallek et al., 1965). Nitrazepam, like diazepam, another benzodiazepine derivative, also has central muscle relaxant properties (Svenson and Gordon, 1965).

In patients with normal lung function nitrazepam does not cause respiratory depression even when the normal therapeutic dosage is exceeded (Matthew et al., 1969). However, three patients with respiratory failure were noted to develop carbon dioxide narcosis after taking nitrazepam as night sedation (Clark et al., 1971). We have studied the effect of a therapeutic dose of nitrazepam $(10 \mathrm{mg})$ in patients with chronic obstructive bronchitis and hypercapnia in a double-blind controlled crossover trial.

\section{Patients and Methods}

Six men were investigated. Their mean age was 65 years (range 50-75), height 1.67 metres (range 1.53-1.78), and weight $58.3 \mathrm{~kg}$ (range 51-73). The nature of the trial was explained and they all gave their consent. All had smoked at least 10 cigarettes daily for a minimum of 20 years. They had been admitted to hospital because of an acute exacerbation of chronic obstructive bronchitis and were assessed for admission to the trial when they had recovered from the acute episode and were convalescent. The

Department of Medicine, University of Aberdeen

J. GADDIE, M.B., CH.B., Research Fellow

J. S. LEGGE, M.D., Research Fellow

K. N. V. PALMER, M.D., F.R.C.P., Reader

Department of Therapeutics and Clinical Pharmacology, University of Aberdeen

J. C. PETRIE, M.B., CH.B., M.R.C.P., Senior Lecturer

R. A. WOOD, B.SC., M.R.C.P.ED. Lecturer

diagnosis at this time was chronic obstructive bronchitis and ventilatory failure (Campbell, 1965; Palmer and Diament, 1970).

During the trial no change was made in concurrent drug therapy. Each patient was studied at the same time on two separate days, at least $\mathbf{4 8}$ hours apart. Arterial blood gas tensions and dynamic lung volumes were measured before and at 30minute intervals up to 120 minutes after either $10 \mathrm{mg}$ of nitrazepam or placebo by mouth, the order of giving the drugs being randomized. On each day, before beginning the study, arterial cannulation of the brachial artery was performed. Blood samples were obtained with a heparinlubricated syringe when the patients were breathing air, and the arterial oxygen tension $\left(\mathrm{PaO}_{2}\right)$, arterial carbon dioxide tension $\left(\mathrm{PaCO}_{2}\right)$, and $\mathrm{pH}$ were measured in duplicate with electrodes manufactured by Radiometer (Copenhagen). The standard deviation for a single measurement in our hands was $1.14 \mathrm{~mm} \mathrm{Hg}$ for the oxygen electrode and 1.02 $\mathrm{mm} \mathrm{Hg}$ for the carbon dioxide electrode. Forced expiratory spirograms were obtained and from the best of three attempts the forced vital capacity (FVC), forced expiratory volume in 1 second $\left(F E V_{1}\right)$, and the $F E V_{1}$ as a percentage of $F V C\left(F E V_{1} \%\right)$ were measured. Volumes were recorded in litres A.T.P.S. (ambient temperature and pressure saturated with water vapour). Normal values for spirometric measurements were derived by using the data of the Committee on Rating of Mental and Physical Impairment (1965), allowing for differences in age, sex, and height.

\section{Results}

The mean results of spirometry and arterial blood gas tensions in the six patients before admission to the trial are shown in Table I. Severe airways obstruction and a restrictive ventilatory defect were present. Hypoxaemia and hypercapnia were severe and the mean $\mathrm{pH}$ was within the normal range so that these patients had ventilatory failure with a compensated respiratory acidosis.

The mean falls in the dynamic lung volumes and blood gas tensions at intervals of 30 minutes for up to two hours after the drug compared with placebo are shown in Table II. The $F_{1}$ and FVC fell significantly $(P<0.01)$ compared with placebo and there was a fall in $\mathrm{PaO}_{2}$ and a tendency for the $\mathrm{PaCO}_{2}$ to rise compared with placebo.

TABLE I-Spirometry and Arterial Blood Gas Tensions in Six Patients with Chronic Obstructive Bronchitis

\begin{tabular}{|c|c|c|c|c|}
\hline \multicolumn{3}{|c|}{ Measurement } & \multirow{2}{*}{$\begin{array}{l}\text { Mean (Range) } \\
0 \cdot 62(0 \cdot 31-0.91) \\
1.71(1 \cdot 01-2 \cdot 25) \\
36 \cdot 4(29 \cdot 0-51 \cdot 5) \\
48 \cdot 5(32 \cdot 0-55 \cdot 0) \\
58 \cdot 4(53 \cdot 0-69 \cdot 0) \\
7 \cdot 42(7 \cdot 37-7 \cdot 48)\end{array}$} & \multirow{2}{*}{$\begin{array}{c}\begin{array}{c}\text { Mean } \\
\text { Predicted } \\
\text { Normal Values }\end{array} \\
2 \cdot 6 \\
3 \cdot 4 \\
76.5\end{array}$} \\
\hline 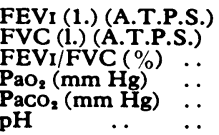 & $\begin{array}{l}\ldots \\
\because \\
\cdots \\
\ldots\end{array}$ & $\begin{array}{l}\because \\
\because \\
\because \\
\because\end{array}$ & & \\
\hline
\end{tabular}

